\title{
MØDER MED ERICA
}

Hvordan mennesker og robotter kalibreres i forhold til hinanden

\author{
KRISTIAN HOECK
}

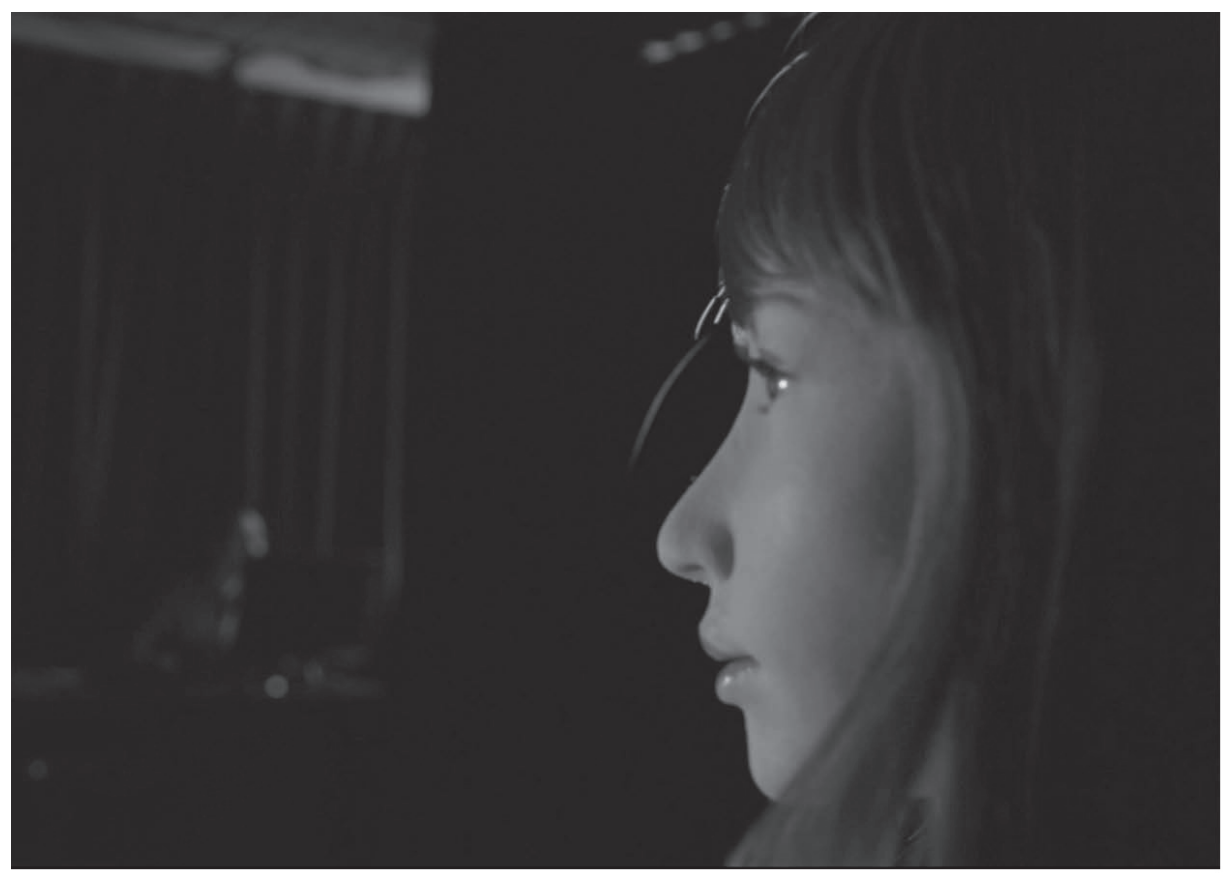

Denne artikel handler om menneske-robot-mødet. Det konkrete møde mellem den semiautonome kommunikationsandroide, Erica, og hendes forskellige samtalepartnere samt mødet som den kommunikative form, der definerer robot-menneske-relationen her.

Med udgangspunkt $\mathrm{i}$ et års feltarbejde på professor Hiroshi Ishiguros to laboratorier i menneske-robot-interaktion (Human Robot Interaction) i Kansairegionen i Japan undersøger jeg iscenesættelsen af robot-menneske-relationer i forskellige møder imellem Erica og mennesker. 
Mit grundlæggende spørgsmål er: Hvordan kalibreres en relation i mødet mellem et menneske og en robot?

For at svare på dette spørgsmål giver jeg eksempler på det arbejde, der udføres på de to laboratorier Intelligent Robotics Laboratory (IRL) og Hiroshi Ishiguro Laboratories (HIL). Her viser jeg, hvordan robotforskerne tester, kortlægger, og implementerer kulturelt medierede udtryk på menneskelig adfærd i robotmenneske-mødet.

At undersøge iscenesættelsen af robot-menneske-relationer på IRL og HIL er ofte konceptuelt forvirrende. Professor Ishiguro og hans stab arbejder $\mathrm{i}$ udgangspunktet ud fra mange principper, der er beslægtet med antropologien: at mennesket er relationelt defineret (Ishiguro et al. 2014; Strathern 1988; Maynard 1997); at relationer kan dannes på tværs af det menneskelige og ikke-menneskelige (Ishiguro 2006; Viveiros de Castro 1998; Helmreich 2009); at mennesket er et materielt betinget, kropsligt intelligent væsen (Ishiguro et al. 2013; Ingold 2007). ${ }^{1}$ Trods disse umiddelbare sammenfald, som jeg gang på gang stødte på i mine samtaler med robotforskerne på det to laboratorier, blev det efterhånden mere og mere tydeligt, at antropologer og robotforskere måske nok benytter en række af de samme begreber, men at vi benytter dem på vidt forskellig vis. Hvor antropologer har tendens til at forankre mennesket i specifikke relationelle kontekster, som vi forsøger at undersøge i deres specificitet, arbejder robotforskerne snarere med begrebers abstrakte og plastiske kvaliteter - det, som antropolog Marilyn Strathern kalder begrebers generiske karakterer (Strathern 2020:27). Netop grundet den manglende specificitet kan robotforskernes konceptualiseringer af mennesket og dets relationelle karakter konkretiseres til en teknovidenskabelig standard og til den, for mig, radikale teknoingeniørmæssige drøm om at kunne reproducere det menneskelige i robotform.

Jeg kan ikke dykke ned i alle disse sammenfald og forskelle her, men har i stedet valgt specifikt at fokusere på, hvad der menes med en relation, som den iscenesættes i robot-menneske-interaktionen. Jeg tager mit udgangspunkt i Stratherns (2014a, 2014b) iagttagelse, at antropologien ofte stopper sit analytiske arbejde, når en relation mellem sociale fænomener er identificeret. Selve relationens kvaliteter, struktur og iboende egenskaber, og hvordan disse konstitueres af og konstituerer de fænomener, der indgår i relationen, forbliver ofte underanalyserede (ibid.). Jeg ser derfor robotforskernes på en gang genkendelige og fremmedartede iscenesættelse af en relation som en kærkommen anledning til at undersøge selve relationens kvaliteter og specifikke udformninger i robotmenneske-mødet.

I min læsning af robotforskernes arbejde iscenesættes robot-menneskerelationen som et interaktivt kommunikationsforhold. Både mennesker og robotter 
behandles som kommunikationssystemer, der skal finde en fælles kommunikativ form, som kan struktureres til robottens algoritmiske forståelse og samtidig udtrykkes gennem mere eller mindre stabile og afkodelige udtryk for menneskeligt samvær. I processen fokuserer robotforskerne på såkaldt menneskelig adfærd som kommunikative, aflæselige og potentielt kodebare tegn.

Selve relationen, foreslår jeg, kan i robot-menneske-mødet forstås som en semiotisk form, hvis egenskaber kommer til udtryk i det kommunikative forhold, formen muliggør. I min brug af form læner jeg mig op ad to komplementære tilgange til begrebet form, som begge på hver deres vis sætter fokus på formen som rammesætningen af det kommunikative rum i robot-menneske-interaktionen.

Den ene tager udgangspunkt i Eduardo Kohns semiotiske udlægning af form. Formen for Kohn er et mønster, som forskellige systemer kan tage del i. Inden for en sådan form kan forskellige væsener med hver deres semiotiske modaliteter relatere til hinanden gennem tegnudveksling (Kohn 2013:157). Det er et sådant mønster - en sådan form - foreslår jeg, forskerne på IRL og HIL prøver at skabe. For at give et bud på, hvad denne form udtrykker, supplerer jeg med et andet formbegreb, det japanske begreb kata (form), der er en performativ form, som koreograferes efter kulturelle repertoirer af struktureret samvær. Det er et lignende repertoire, jeg ser i en række samtaler mellem Erica og tre af professorens sekretærer.

Om end mine informanter ikke eksplicit omtaler disse to former, tillader jeg mig alligevel at rammesætte mine etnografiske betragtninger med disse to formbegreber, da robotforskerne i deres arbejde analyserer og implementerer mønstre for samvær til deres robotter, så de kan programmeres til at performe menneskelignende adfærd. Jeg foreslår, at robotforskernes derfor i deres teknovidenskabelige praksis benytter sig af lignende formgreb, og at deres robotmenneske-interaktioner iscenesættes som både et programmerbart mønster og et kulturelt medieret udtryk, der tilsammen skaber en relationel performance.

Med disse to udlægninger af form bliver mit postulat, at i robotforskernes iscenesættelse bliver selve relationen rekalibreret som en form, der kan afstemmes til både et algoritmisk kodet og et kulturelt medieret adfærdsmønster. I processen bliver både robotter og mennesker standardiseret til en teknokulturel kalibrering af menneskelig adfærd.

\section{Strategisk relationsskabelse}

Jeg er så langtfra den første antropolog, der har undersøgt robot-menneske-relationer med fokus på Japan, hvor det ofte er blevet bemærket, at japanere tilsyneladende ikke har noget problem med at acceptere robotter iblandt sig som del 
af et fælles kulturelt og relationelt ophav (Robertson 2007; Richardson 2016). Det, som kendetegner forholdet mellem robotter og mennesker i Japan, er ifølge antropolog Jennifer Robertson (2017), at frem for at fremhæve robotter og menneskers ,artsforskelle“ defineres robotter ud fra, hvordan de er relationelt forbundet til mennesket („the manner of their bonding“) (Robertson 2017:131) Det er iscenesættelsen af denne forbindelse, jeg undersøger i indeværende afsnit, da den tydeliggør den relationelle grund, som robotterne skabes på, og illustrerer de kulturelt medierede og værdiladede udtryk, robotterne rammesættes med for at kunne accepteres af den japanske befolkning.

Japan, ofte refereret til som „robotriget" (,the Robot Kingdom") (Schodt 1988), har siden 2. verdenskrig positioneret sig som en førende nation inden for robotindustrien (Berthin 2014:16). Robotter optræder i de populærkulturelle fænomener manga og anime, $i$ historiske narrativer og $\mathrm{i}$ den nationale diskurs - ofte i positivt konnoterede relationer til det menneskelige i rollen som ven, som hjælper eller som en del af den japanske „familie“ (Robertson 2010:10) Humanoide robotter i Japan anvendes både inden for terapi, i plejesektoren, i undervisning, som spirituelle guider, som ,ansatte“ i stormagasiner og hoteller og som sociale partnere i hjemmet (Kubo 2010; Coeckelberg 2012; Robertson 2017; Leeson 2017).

De forskellige felter, som robotter i Japan optræder inden for, har ifølge antropolog Kathleen Richardson (2016) skabt et kulturelt narrativ, hvor robotter og mennesker potentielt kan eksistere i harmonisk fællesskab, og hvor robotter kan betragtes som japanske indfødte. Samtidig viser mere kritiske studier af japanske robotter dog, at disse endemiske fremstillinger af japanske robotter er et produkt af en bevidst indsats fra regeringens, industriens og forskningens side for at opfordre befolkningen til at acceptere robotterne iblandt sig (Wagner 2009; S̆abanović 2014). Det er særligt denne sidste pointe, jeg vil fremhæve i indeværende afsnit, da den ikke blot sætter fokus på det strategiske og diskursive arbejde, der ligger i at skabe mulige robot-menneske-relationer, men også de kulturelle, spirituelle og nationale troper, der mobiliseres for at give robotmenneske-relationer deres karakteristika.

Blandt japanske robotforskere selv fremhæves den japanske shintospiritualitet ifølge Richardson ofte, når den potentielle relationelle forbindelse mellem menneskelige og ikke-menneskelige verdener skal underbygges (Richardson 2016:112). En af shintospiritualitetens grundpiller er den vitale kraft kami, som strømmer igennem den materielle verden og indgyder hele universet med liv. I shinto kan liv tage bo i alle slags materielle genstande - herunder også robottens materielle krop (Robertson 2007:377). Shintospiritualitet fremhæver en verden, hvor guder, mennesker, dyr, objekter og planter er del af et samlet, dynamisk 
eksistensfelt karakteriseret af indbyrdes afhængighed og kontinuitet (Jensen \& Bloch 2013:97). Robotter i Japan bliver med reference til shinto ofte italesat - både af robotforskere, i den nationale diskurs under Shinzo Abe og i den akademiske litteratur (Robertson 2017) - som repræsentanter for et ikke-dualistisk verdensbillede. Her står teknologisk medieret materialitet ikke i opposition til det spirituelle, natur står ikke i opposition til det kunstigt frembragte, og mennesket defineres ikke ud fra sin biologi, men ud fra social og spirituel samhørighed med den materielle verden (Clammer 2005; Coeckelbergh 2013; Jensen \& Bloch 2013). Spirituel samhørighed, som den fremskrives her, er dermed ikke en forbindelse mellem distinkte entiteter, men snarere den relationelle grund, hvorpå alt liv dynamisk konstitueres.

Som Robertson imidlertid fremhæver, er fusionen mellem spiritualitet og robotteknologi i høj grad også strategisk og politisk konnoteret og fremhæver japanske traditionelle værdier, som robotter kan være bærere af (Robertson 2007, 2010, 2018). Om end robotforskerne optimistisk retter blikket mod en fremtid med spirituel-teknologisk harmoni og en udvidelse af begrebet menneske, reproducerer de samtidig en konservativ verdensorden med kønshierarki og traditionelle værdier. Ifølge Robertson er robotter i Japan designet til at passe ind i det japanske samfund under det overordnede ideal om familien som det sociales grundkerne (Robertson 2017:131). Den japanske robot er for Robertson en værdiladet kropsliggørelse af idealet om, at alle japanske subjekter udfylder en rolle som medlemmer af én stor patriarkalsk familie. Set i dette lys er relationen mellem robotter og mennesker fremskrevet som et slægtskab, der ikke forudsætter et blodsbånd, men er defineret ud fra de relationelle roller, der forefindes inden for familiens overordnede struktur.

Hos forsker i informationsvidenskab Selma Šabanović (2014) er det ikke familien, men de performative udtryk, der fremhæver en kulturelt båret forbindelse mellem robotter og mennesker, når japanske robotter fremfører kulturelle og rituelle performances, hvor de iføres traditionelle klædedragter, reciterer japanske digte, fremfører japansk folkemusik eller optræder i teaterproduktioner. Her er robot-menneske-relationer iscenesat som et fælles kulturelt og traditionsbåret ophav, som både robotter og mennesker kan tage del i. Både Robertson og Šabanović fremhæver dermed robotterne som kulturelle skabninger, der er indfødt japanske, trods deres biologiske artsforskelle.

Fælles for disse analyser er, at de fremhæver de kulturelle fællesnævnere, som robotforskere benytter sig af for at skabe mulige forbindelser mellem robotter og mennesker, mens de iboende forskelle imellem dem nedtones. Disse strategier skal ses i lyset af, at humanoide robotter ofte er notorisk svære at få til at udtrykke, hvad de skal udtrykke (Suchman 2011). Menneskelignende robotter 
er ofte tvetydige skabninger, der kan være svære at aflæse entydigt, og de er konstant $i$ fare for at falde ned i ,the uncanny valley“ (Mori 1970; Richardson 2016) som det uigenkendelige kendte, en kategorisk ustabil, levende og ikkelevende skikkelse, der udtrykker menneskelig lighed og umenneskelig adfærd på en og samme tid. Denne kategoriske usikkerhed gennemsyrer arbejdet med menneskelignende robotter, hvor robotforskerne på hver deres vis forsøger at kompensere for robotternes tvetydige status. Det er her, de overliggende strategier, diskurser og værdiladede udtryk kommer i spil.

Hvad jeg savner i de foreliggende analyser, på baggrund af mine egne observationer af de konkrete kommunikative udvekslinger mellem mennesker og robotter på IRL og HIL, er, hvordan selve mødet mellem mennesker og robotter kalibreres og samtidig kalibrerer den mulige relation imellem dem. De ovenstående analyser forholder sig primært til den diskursive iscenesættelse af en sådan relation frem for til selve robot-menneske-interaktionen. Mit forslag er her, at i menneskerobot-interaktionen bliver ovenstående diskursive iscenesættelser omskrevet til kodede adfærdsmønstre, som både (japanske) robotter og (japanske) mennesker kan kalibreres til, hvilket indebærer, at disse iscenesættelser bliver standardiseret til en fælles kommunikativ form.

\section{Menneskeligt kommunikationssystem}

Den ovenstående gennemgang har tydeliggjort, at forholdet mellem robotter og mennesker i Japan ofte medieres gennem kulturelle narrativer, traditioner og spirituel samhørighed, men også at denne mediering er politisk ladet og bundet op på traditionelle værdier om køn, japansk homogenitet og passende roller for det japanske subjekt. Forsøget på at skabe forbindelser mellem robotter og mennesker iscenesætter robotter som en særlig type menneskelignende figurer, der definerer dem ud fra deres tilhørsforhold til og deres potentielle roller inden for det japanske samfund. Min etnografiske tilføjelse til denne tilgang er, at i selve menneskerobot-mødet eksperimenterer robotforskerne med en teknologisk kalibrering af den kulturelle rammesætning til robotternes menneskelignende udtryk.

Jeg bygger denne analyse på det etnografiske materiale, jeg indsamlede under mit årsophold på professor Ishiguros to laboratorier, hvor jeg havde fast base på IRL og hyppige besøg på HIL. Min undersøgelse har kredset om begrebet menneskelighed og om, hvordan „det menneskelige“ tager sig ud i robotforskernes iscenesættelse. Til denne artikel har jeg begrænset mig til at undersøge robotforskernes begreb interaktion som en særlig relationel størrelse, der figurerede centralt i deres egne beskrivelser af det arbejde, de udførte, de problematikker, de stod over for, og i deres målsætning om at skabe robotter, 
der kunne kommunikere med mennesker. Begge laboratorier arbejder inden for det tværfaglige, teknovidenskabelige område kaldet menneske-robot-interaktion. Forskningen på IRL og HIL er dermed først og fremmest et studie af forholdet mellem robotter og mennesker snarere end af robotten (eller mennesket) som enkeltstående skabninger. Det officielle formål med dette arbejde handler om at udvikle „den sociale relation“ (Ishiguro et al. 2006:2) mellem robotter og mennesker og på sigt skabe robotter, der kan accepteres af og indgå i den japanske befolkning. IRL og HIL masseproducerer ikke deres humanoide robotter til kommercielt eller privat brug. Snarere fungerer robotter som Erica som eksperimentelle sociale prototyper i, hvad robotforskerne på de to laboratorier refererer til som, ,grundlæggende forskning“ i mulige typer af interaktion mellem robotter og mennesker.

Interaktion, erfarede jeg i løbet af mit feltarbejde, fremhæver robotter og mennesker på specifikke måder og gør spørgsmålet om robot-menneske-relationen til et, der omhandler kommunikation. På IRL og HIL figurerede interaktion og kommunikation som hinandens ækvivalenter og blev brugt af robotforskerne til at beskrive det konkrete møde mellem robotter og mennesker, men i lige så høj grad som en epistemologisk forklaringsramme for menneskelig væren, socialitet, selvet og intelligens. Interaktion, fortalte professor Ishiguro mig, er nøglen til at forstå det „menneskelige metaniveau“" såsom „,menneskets socialitet". Mennesket, uddybede professoren, skal grundlæggende forstås kommunikativt gennem den information, vi udveksler mellem hinanden. „Hvordan kan vi sende og modtage beskeder til hinanden? Hvordan kan vi forstå en anden person? Hvordan kan jeg kommunikere mig selv til en anden. Det er mennesket." ${ }^{\text {2 }}$

Ved at rammesætte det menneskelige som et kommunikativt forhold, foreslår jeg, skaber robotforskerne på IRL og HIL forudsætningerne for, at deres humanoide robotter kan tage del i et sådant trods deres iboende teknomaterielle andethed. Menneskelige egenskaber bliver gjort til et spørgsmål om målbar information, som kan afkodes og dernæst reproduceres og implementeres med digitale og ingeniørtekniske midler. I robotforskernes arbejde omformes menneskelig adfærd til kodebare data. I min læsning af dette er jeg inspireret af antropolog Grant Otsukis (2015) undersøgelse af humancentreret teknologi, herunder også professor Ishiguros humanoide robotter. Human Centred Technology er designet med den menneskelige bruger for øje og handler om at skabe teknologier, der kan kommunikere med mennesker på tværs af menneskers og teknologiernes indbyggede forskelle. I processen med at designe sådanne teknologier, observerer Otsuki, bliver mennesket artikuleret som et kommunikationssystem. I en sådan optik defineres mennesket ved sin egen karakteristiske måde at, ,modtage, behandle og transmittere information" på (Otsuki 2015:ii). At skabe kommunikation mellem 
mennesker og andre kommunikationssystemer kommer dermed til at handle om at skabe teknologiske grænseflader, der gør det muligt at udveksle information imellem dem (Otsuki 2015:3). Jeg ser et lignende træk i IRL's og HIL's artikulation af det menneskelige i samspil med deres robotter. I deres arbejde, foreslår jeg, artikuleres det menneskelige ud fra kommunikative parametre, som kan anvendes for både robotter og mennesker. Om end robotforskerne tager deres udgangspunkt i studier af menneskelig adfærd og menneskelige egenskaber - ofte inspireret af eksperimentel psykologi og kognitionsvidenskab - rekalibreres denne adfærd og disse egenskaber til kommunikative standarder, som både robotter og mennesker kan benytte sig af i deres fælles møde.

At arbejdet på IRL og HIL ofte handler om at udvikle kommunikative standarder på menneskelig adfærd, blev især tydeligt for mig, da jeg begyndte at følge arbejdet med at kode algoritmerne til laboratoriets robotter på baggrund af sociale eksperimenter med menneskelige forsøgspersoner. I disse sociale eksperimenter undersøger forskerne „,menneskelig adfærd“, som kortlægges og (optimalt set) udvikles til algoritmer for robotten i kodesprogene Python, $\mathrm{C}++$, C-sharp og JAVA.

"Jeg leder efter, hvilken adfærd der er naturlig i mødet mellem mennesker,“ fortæller ph.d.-studerende på IRL, Yang, mig. ${ }^{3}$ Han er ved at fastgøre videokameraet i det lille forsøgslokale og drejer det hen mod bordet og de to stole, der er placeret side om side. Rummet er omkranset af sorte væg-til-gulv-gardiner. Et af gardinerne skærmer af ind til et lille rum, hvor Yang har placeret alle sine monitorer og computere, der skal registrere den menneskelige udveksling, han undersøger. Hans projekt omhandler såkaldt „,intime situationer“, som han kalder det, mellem mennesker og de kropslige og sproglige „mønstre“, der indgår i et sådant samvær. Det er et robotløst eksperiment, hvor to forsøgspersoner ad gangen bliver bedt om at føre en „fri“" samtale, mens de sidder ved siden af hinanden. Bagefter bliver de bedt om at diskutere en række fotos, som den ene har taget med. Nogle af parrene er kærester, andre er venner. Imens de taler, sidder Yang på den anden side af gardinet og følger med på sine monitorer, mens han tjekker, at computerne registrerer og aflæser de kropslige og auditive mønstre, som kommer til udtryk i deltagernes kropssprog og tale. Hans mål er at implementere disse mønstre til Erica for at „forbedre forholdet“" (the relationship) mellem mennesker og robotter. „I menneskelig adfærd må der være regler og mønstre, og de mønstre kan programmeres ind i Erica.“

Yangs eksperiment her er et eksempel blandt mange, som jeg ser som emblematiske for de to laboratoriers tilgang til interaktion. Begreber, der beskriver social interaktion mellem mennesker, bliver struktureret som skematiske systemer over standardiseret menneskelig adfærd. Spørgsmålet for robotforskerne her synes ikke så meget at omhandle disse begrebers (som for eksempel intimitet) grundlæggende 
karakter, men snarere, hvordan de kan kalibreres til maskinlogik og til mødet mellem mennesker og robotter. Menneskelig adfærd bliver dermed standardiseret til robotternes kommunikationssystemer som operationelle modeller, der kan anvendes i interaktionen mellem robotter og mennesker. Det robotteknologiske repertoire artikulerer menneskelig adfærd ud fra de tekniske systemers ydeevne og begrænsninger.

Hvad jeg imidlertid også vil fremhæve her, er, at sådanne strukturerede former kan forstås som forsøg på at kalibrere en relation, og at formen kan anskues som den strukturerede og strukturerende ramme for relationen. Her tager jeg udgangspunkt i det japanske begreb kata, som oversættes til form, men som har sine helt egne konnotationer. Med afsæt i, hvad han kalder The Zen Arts, undersøger antropologen Rupert Cox (2003) kata som et repertoire af strukturerede æstetiske og performative former, der udtrykker et relationelt forhold. I Cox' etnografi finder han ofte denne „form“ i ritualiserede, sociale handlinger som i teceremonier, kampsport, kunstneriske udtryk som poesi og teater og religiøse højtideligheder. Om end Cox tydeligst ser kata i sin reneste form i de ritualiserede og traditionelle praksisser, som han studerer, er hans påstand, at kata er en gennemgribende tilgang til det sociale i Japan, som kultiverer en bestemt slags japanske subjekter. Kata er ifølge Cox først og fremmest en æstetisk praksis, hvor kroppen og sproget gennem formaliserede og indøvede bevægelser og ytringer udtrykker en autentisk samhørighed efter bestemte, standardiserede kulturelle forskrifter. Det æstetiske står her i Cox’ udlægning ikke i opposition til det autentiske. Estetiske udtryk er autentiske udtryk for en relation inden for afkodelige, strukturerede sociale former. Relationen skabes her i formen gennem en koreograferet performance. Kata er dermed en form, som skaber sin egen sandhed. Det er ikke form over indhold, det er form som indhold.

I robotforskernes udvikling af algoritmer for deres robotter og i deres iscenesættelser af robot-menneske-mødet ser jeg et lignende fokus på det relationelle som udtrykt i strukturerede og formaliserede former for samvær. Hos programmørerne på IRL og HIL er fokus netop på, hvordan visse fastsatte former for interaktion aktualiseres i performative iscenesættelser, og hvordan en autentisk relation kan skabes med teknisk kontrollerede repertoirer af socialt kodebar adfærd. Ved at kalibrere det sociale til systematiserede interaktioner mellem mennesker og robotter kultiveres både mennesker og robotter i henhold til funktionelle standarder i specifikke former for interaktion. Min pointe med denne analogi er at foreslå, at for forskerne på IRL og HIL er det sociale ikke blot noget, der kan kalibreres, struktureres og kodes, men noget, der allerede er kalibreret, struktureret og kodet og derfor kan implementeres til robotter - eller som Yang siger: - „I menneskelig adfærd må der være regler og mønstre.“ 
Denne læsning har betydning for mit overordnede spørgsmål, da den sætter fokus på de relationelle rekalibreringer mellem mennesker og robotter. En autentisk relation kan frembringes med tekniske midler, kan udtrykkes i dechifrerbar adfærd og kan dermed udveksles over de kommunikative grænseflader mellem robotter og mennesker. Her er det netop de parametre, der definerer mennesker og robotters performative ydeevne, som bliver den målbare størrelse for det menneskelige samvær, som robotter kan tage del i. Det er grundlæggende sådan, jeg forstår det, når professor Ishiguro og hans hold af forskere omsætter al menneskelig adfærd til kommunikative tegn og målbare data. Det ægte ligger i den kommunikative form.

Jeg vil i de følgende to afsnit give eksempler på, hvordan en sådan form performes, og de kommunikative registre, som androiden Erica og forskellige menneskelige samtalepartnere benytter sig af. Som vi skal se, er en succesfuld kalibrering af en fælles kommunikationsform for mennesker og robotter langtfra givet. Grundet Ericas og menneskers forskellige systemer for tegnaflæsning kan en sådan kalibrering lige så ofte føre til forvirring og kommunikationssammen brud.

\section{Goddag mand, økseskaft}

Erica er uden sammenligning den mest menneskelignende af alle IRL's og HIL's humanoide robotter. Glansen i hendes kastanjebrune hår, glimtet i hendes øjne, hendes lyse marcipanhud, hendes smilehuller giver en slående lighed med en elegant, ung kawaii (nuttet) japansk kvinde, som robotforskerne ofte pointerer med stolthed, når de fremhæver Ericas skønhed og hendes realistiske fremtoning. Som regel holder hun til i sit eget rum på HIL, indrettet som et venteværelse med to identiske gråternede sofaer og et sofabord dekoreret med plastikblomster. Når Erica ikke er i brug, sidder hun med hænderne tålmodigt hvilende i skødet, ventende på, at det næste menneske kommer forbi. Når hun får besøg, møder hun sin samtalepartner med en sukkersød optimisme, et høfligt buk og et uudgrundeligt smil.

Mens Ericas krop fremstår som en komplet helhed afgrænset af hendes bløde silikoneoverflade, er de systemer, der styrer Ericas ydeevne, et distribueret netværk af programmer og artefakter, som ikke er afgrænset af hendes anatomiske krop. På sofabordet skjuler arrangementet af plastikblomster en højtaler, som transmitterer Ericas stemme, og en række mikrofoner, der opfanger Ericas samtalepartneres tale. Rundt om sofaarrangementet kortlægger et antal KINNECT-kameraer rummet og skaber en 3D-komposition, der fungerer som Ericas visualisering af rummet og fortæller hende, hvor hendes samtalepartner er placeret. Informationen fra 
mikrofoner og kameraer behandles i et program, der kaldes Geminoid-serveren, og som er fælles for alle laboratoriets humanoide robotter. Geminoid-serveren distribuerer informationen til programmer, der kan analysere tale og genkende menneskelige ansigter. Til sidst bearbejdes informationen af en af Ericas samtaledatabaser og af styresystemet, der kontrollerer hendes bevægelser. Tilsammen genererer disse programmer Ericas svar verbalt sammen med et afstemt kropssprog, ansigtsudtryk og toneleje.

Som denne beskrivelse tydeliggør, er Erica ikke en entydig skabning. Det er en kompliceret affære at få Ericas menneskelignende udseende, hendes forskellige systemer for tegnudveksling og hendes programmerede adfærd til at gå op i en højere enhed. På baggrund af de tidligere afsnits eksempler argumenterer jeg her for, at Erica bliver standardiseret til kategoriske typer af menneskelighed, der lever op til kulturelt medierede forskrifter for udseende og adfærd. Erica udfylder på sin vis en bestemt, kønnet og værdiladet rolle (Robertson 2017), ${ }^{4}$ der skal kommunikeres i hendes interaktive performances.

At en sådan performance ikke altid lykkes, blev særligt tydeligt for mig, da jeg overværede en præsentation af Erica for en amerikansk dokumentarist og hendes assistent $\mathrm{Yu}$, som interviewede Erica for rullende kameraer.

„Føler du dig ensom her for dig selv?“

Erica reagerer ikke på spørgsmålet. Hendes hoved forbliver lidt på sned med hendes afventende, uudgrundelige smil rettet mod Yu, som sidder skråt over for hende i den anden sofa.

„Hvad med at jeg vender tilbage til det senere?“ svarer Erica endelig i en let kvidrende tone. Hendes engelske er formfuldendt om end lidt mekanisk, hendes stemme er fløjlsblød, men med en diskant skrattende efterklang.

„... Er der andet, du gerne vil vide?“

Yu ser ned på listen med de medbragte spørgsmål, han holder foran sig.

„Hvad slags mad spiser du?“

Erica bøjer hovedet. Hendes smil forsvinder, og hendes stemme falder en halv oktav til et mere alvorligt leje. „Det uheldige ved at være en androide er, at jeg ikke kan nyde oplevelsen af menneskelig mad.“

Yu bøjer sig lidt frem. „Men kan du lugt...“

„... Jeg ville gerne prøve [mad], men jeg tror, det ville gå i mine aktuatorer,“ fortsætter Erica, nu igen i et muntert leje.

„Okay ..." siger Yu tøvende.

„,... Når det er sagt ... “ fortsætter Erica.

„Har du? ...“

„,... så fik jeg et solidt morgenmåltid af 100 volt - og selvfølgelig 60 hertz ...“ „Jeg ..." prøver Yu at få indskudt.

„... Ærlig talt, så er 50 hertz-elektriciteten i Tokyo yderst smagløs,“ afrunder Erica, „... Har du andre spørgsmål til mig?“

Yu kigger sin liste af spørgsmål igennem. 
„Jeg tænkte faktisk på, føler du dig som menneske eller ej?“

„Tjoh, har du nogle steder, du gerne vil besøge?“

Denne lettere pinefulde samtale står på i en halv time, før Andrea og Yu er færdige og pakker deres udstyr sammen. Yu ser både lettet og lettere rystet ud. Vi slår følgeskab til den nærmeste togstation. Andrea rejser jorden rundt for at møde de mest prominente robotter i verden, fortæller hun. Efter mødet med Erica er hun tydeligt skuffet. „Den var godt nok ikke særlig god,“ konstaterer hun ærgerligt. Yu ryster samtykkende på hovedet.

Hvad jeg ser som problemet i dette kommunikationssammenbrud mellem Erica og Yu, bunder i en kontekstuel forvirring. I min tilgang til kontekst her står jeg i gæld til antropolog Gregory Bateson, hvor kontekst er det, som gør udveksling af information meningsfuld, når konteksten deles af afsender og modtager, men som samtidig også kan lede til kommunikationssammenbrud, hvis afsender og modtager benytter sig af vidt forskellige kontekster for meningsfuldhed. Betydningen af information er på sin vis sin egen kontekst, da konteksten ifølge Bateson er den form som information tager, og dermed det, som tilkendegiver, hvad information omhandler (Bateson 1972:124). Ovenstående samtale illustrerer, hvad der sker, når det ikke lykkes for Erica og hendes samtalepartnere at blive enige om et repertoire, der gør kommunikationsudvekslingen meningsfuld. Med andre ord, deres adfærd fulgte ikke et kompatibelt mønster, der kunne kalibreres på tværs af deres respektive kommunikationssystemer.

Pointen med at inddrage Batesons kontekst i diskussionen her er, at den gør spørgsmålet om at kommunikere med Erica til et spørgsmål om at rammesætte betydningen af den information, der udveksles mellem Erica og hendes samtalepartnere, og dermed skabe en kontekst, der gør informationen gensidigt aflæselig. Problemet med at kommunikere med Erica, som Yu oplever på første hånd her, er, at hvor Ericas kropslige tilstedeværelse udtrykker en menneskelignende tilstedeværelse, er Ericas kommunikationssystem drevet af en egen informationslogik, som vi så i det ovenstående afsnit. I mødet med Yu opstod der forvirring om, hvad den information, som Erica udsender, handler om. Erica udsender blandede og ofte paradoksale tegn på både noget genkendeligt menneskeligt og noget ikke-menneskeligt. Dette på en gang forvirrende og velkendte møde med Erica hænger sammen med, hvad jeg vil foreslå at kalde Ericas multivalens som tegn. Hendes ytringer er ikke udtryk for egne tillærte erfaringer, ønsker eller behov, men er scriptet af robotforskerne som algoritmer, der fungerer som strukturerede mønstre for menneskelig, kommunikativ adfærd. Ericas sprog er dermed ikke betegnelser for Ericas erfaringer, men er organiserede kommunikationsmønstre, der muliggør udveksling af information ved brug af et struktureret repertoire af udsagn og modsvar. 
Kommunikationssammenbruddet kan dermed ikke kun tilskrives Erica, men i nogen grad også Yus manglende evne til at aflæse og kommunikere med Erica på en for hende meningsfuld måde. I mødet med Ericas manglende evne til at tilpasse sig formåede Yu heller ikke at tilpasse sig hende. Både Yu og Erica holdt sig til deres prædefinerede manuskript. Erica fulgte sine scriptede udsagn og strukturen for sine „samtaleemner“ til dørs uden at give plads til, at Yu kunne få en bemærkning indskudt. Yu klamrede sig til sine medbragte spørgsmål, som ikke var formuleret på en måde, som Erica kunne afkode, og som Yu ikke formåede at afvige fra $\mathrm{i}$ situationen. Yu og Erica forblev på hver deres side af en kommunikationskløft, og ingen af dem formåede at indgå i en fælles, kommunikativ form, hvori deres respektive udsagn kunne blive meningsfulde for den anden.

Hvad dette mislykkede møde viser, er, at for at Erica kan indgå i en menneskelig form med en anden, er hendes menneskelignende udseende og hendes sproglige og kropslige udtryk ikke nok i sig selv. For at en mulig relation kan skabes på tværs af robottens og menneskets kommunikationssystemer, foreslår jeg, kræver det to parter, der kan finde en fælles form på tværs af deres indbyggede forskelle. Det er dette, jeg vil illustrere i artiklens sidste del, der tager udgangspunkt i tre møder mellem Erica og tre lydhøre samtalepartnere, hvor jeg samtidig belyser, hvad en robot-menneske-relation kan defineres som, hvordan den bliver struktureret, og hvilke egenskaber den rummer.

\section{Relationskalibrering}

Omkring halvvejs gennem mit feltarbejde har professor Ishiguro opdaget, at jeg har et videokamera med i felten. Han kontakter mig, da han ønsker at få lavet en række nye præsentationsvideoer, som skal vises på en kommende konference for andre robotforskere. „Vi har udviklet et mere naturligt konversationsmønster for Erica," forklarer han mig. Formålet med videoerne er at demonstrere dette system og vise, „hvordan Erica kan eksistere i verden“. Det nye system, der er udviklet til Erica af robotforskerne ved HIL under lektor Minatos ledelse, bygger på tidligere dialogsystemer, men har tilføjet et antal fyldord såsom so desu ne (det er rigtigt) og honto desu ka (virkelig?) for at udfylde nogle af de utilsigtede pauser i samtalen.

Til denne præsentation har professor Ishiguro inviteret tre af sine syv sekretærer til på skift at have en samtale med Erica. De lytter opmærksomt, mens professoren instruerer dem i, hvordan de skal opføre sig under samtalerne. Han beder dem om at tale til Erica som til et menneske, de lige har mødt. „Du skal tale høfligt og være opmærksom på Erica. Vær tålmodig med hende, og vent på, at hun afslutter sine udtalelser." Mens professoren giver sekretærerne anvisninger, 
forbereder Minato-sensei og tre af hans ph.d.-studerende Ericas systemer og indlæser det nye script til hendes samtale.

Suzuki, den første af sekretærerne, sætter sig ned på sofaen over for Erica og hilser med et diskret buk og et smil. Ericas blik finder Suzuki, og hun vender sin overkrop mod hende. Hun smiler. Suzuki smiler tilbage.

„Jeg hedder Erica. Dejligt at møde dig.“

„Dejligt at møde dig også,“ svarer Suzuki hjerteligt.

„Nå men ...."Erica drejer hovedet let på sned og smiler, som hun næsten altid gør, når hun stiller spørgsmål. ,... Kan du lide foråret?“

„Ja, jeg kan godt lide foråret. Det er dejligt, at det er varmt.“

Der er en pause, mens Erica ser på Suzuki med sit uudgrundelige smil. Suzuki smiler tilbage. Så udbryder Erica med en munter stemme: „Ja, det er sandt! Jeg kan også godt lide foråret. Det er en vidunderlig tid. Kirsebærblomsterne er meget smukke om foråret."

Suzuki smiler entusiastisk: „Ja, de er dejlige. Meget smukke. Jeg kan bare blive ved med at kigge på dem.“

„Faktisk ...“"Erica bøjer hovedet med et alvorligt udtryk i ansigtet, „... jeg kan ikke engang nyde jordbærrene. Og jeg har kun set billeder af kirsebærblomster.“

Suzuki nikker forstående, hendes mund er vendt nedad i tilkendegivelse af sympati.

„Det er sandt. Du har nok ikke haft mulighed for det.“

„Suzuki, tager du ofte ud til forskellige steder?“

Suzuki overvejer svaret et kort øjeblik: „Tjah ... jeg går vel faktisk ikke så meget ud, “ indrømmer hun tøvende.

„Virkelig?“ Ericas ansigt lyser op. „Er du også en indeperson?“

„Tjah, jeg kan egentlig både lide at være inde og ude.“

Erica kigger uudgrundeligt på Suzuki. „Er du også en indeperson?“

„Ja, jeg er en indeperson.“”

„Er det sandt?“ udbryder Erica med begejstring i stemmen. „Så er du ligesom mig."

„Ja, det er sandt,“ nikker Suzuki bekræftende.

Denne samtale er en forkortet version af de tre lange samtaler, jeg optog med Erica og de tre sekretærer. Scriptet, som Minato anvendte på Erica her, genereres, så samtalen potentielt kan fortsætte i timevis. Hver af de tre samtaler varede omkring 20 minutter, før Minato stoppede programmet. Mens Erica i disse møder stadig kom med en række aparte udtalelser og af og til holdt lange, uudgrundelige pauser, forløb samtalerne over lange stræk mere eller mindre flydende. Da jeg senere viser videoerne til professor Ishiguro, udbryder han: „De her samtaler virker næsten naturlige. Det er vigtigt, at vi viser et ærligt billede af, hvordan Erica kan fungere i verden.“

Hvad der lykkedes her, foreslår jeg, er, at Ericas forbedrede kommunikationssystem, sekretærernes evne til at adaptere til Erica, samtalens respektfulde høflighedsform og robotforskernes intentionelle iscenesættelse af mødet tilsam- 
men skaber en form, som både sekretærer og Erica kan tage del i. Formen fungerer som en kalibrering af Ericas og sekretærernes forskellige kommunikationssystemer ved at benytte et repertoire af performative udtryk, som både Erica og sekretærerne kan benytte sig af og udveksle med hinanden. Dette repertoire er struktureret på en måde, der er tilpasset Ericas standardiserede adfærdsmønstre, og som samtidig er struktureret efter en kulturelt medieret standard for høflig udveksling mellem fremmede, som sekretærerne er flydende i.

Disse elementer udgør tilsammen en form, der - inspireret af Kohn - følger et mønster, som gør informationsudveksling mulig på tværs af Erica og sekretærernes væsensforskel. Samtidig er denne form ligesom kata en udveksling, der udtrykker en relation imellem de to parter gennem et repertoire af performativ adfærd. Selve iscenesættelsen af samtalen indrammer Ericas og sekretærernes interaktion ud fra forskrifterne for en samtale mellem fremmede. Inden for denne ramme har Minatos hold programmeret Erica ud fra deres forestilling om høflig smalltalk, og Erica er således udstyret med emner, der fungerer som en slags standardiserede udtalelser, der anses for passende til dette: vejr og årstid, film, bøger, japansk mad, lokale attraktioner. Inden for denne rammesætning formår både Erica og sekretærerne at følge forskrifterne for en sådan samtale på en måde, der giver udtryk for en autentisk relation. De responderer passende på hinanden, giver udtryk for interesse, tilkendegiver respekt ved tiltale, nikker, kommer med udbrud af begejstring eller forundring. Kort sagt lever de begge op til det performative udtryk og deres respektive roller, som formen tilskriver. En sådan udveksling foreslår jeg kan læses som en kata.

Når samtalerne mellem Erica og sekretærerne til dels lykkes, er det, fordi formen følger en kommunikativ struktur, som både kan afstemmes til kodesprog og til kulturelle koder for adfærd. Dette bliver særligt tydeligt, hvis vi ser på den sproglige form og de tilhørende kropslige udtryk. På et programmeringsteknisk niveau er disse japanske høflighedsfraser lettere at kode og afkode end uformel jargon eller det lettere uforudsigelige engelske, som Yu blandt andet benyttede over for Erica. Formel japansk tale følger ofte en fast sætningsstruktur, har faste endelser og benytter et repertoire af standardhøflighedsudvekslinger med dertilhørende kropssprog, som følger et forholdsvis fast mønster (Lebra 2004:43; Cox 2003:71). Det kan vi se i måden, hvorpå både sekretærerne og Erica benytter sig af de korrekte ytringer, små buk, skift i toneleje, udtryksfulde bekræftelser af den andens udsagn. Grundet dette repertoires forudsigelige struktur kan Erica benytte sig af det, og hun kan afkode ytringerne fra sekretærerne som klare tilkendegivelser af en sætnings afslutning, præcist formulerede spørgsmål og utvetydige svar. Samtidig udtrykker sådanne udvekslinger i formel japansk interaktion ifølge antropologen Takie Lebra (2004) netop en relation mellem de interagerende parter 
vist igennem grader af høflighed og respekt. Japansk tale, hævder Lebra, følger en betingelseslogik (contingency logic) (op.cit.19), hvori afhængighed ikke står $i$ opposition til autonomi. I høflig japansk tale er relationen ofte fremskrevet som asymmetrisk, hvor man i mødet med en ligeværdig part ofte underspiller sig selv og underlægger sig den anden i samtalen, som man (sprogligt og kropsligt) giver hovedrollen. Opmærksomheden rettes mod den andens tilstedeværelse som et menneskeligt subjekt (op.cit.21). Betingelseslogik er dermed en logik, som kan kalibreres til den andens måde at kommunikere på. Og måske vigtigere her: Det er ifølge Lebra i selve mødet, i det delte rum, at (op.cit.34) betingelseslogik fremskriver det relationelle forhold gennem sprogets grammatiske struktur, og hvordan denne struktur udtrykker de talendes roller i forhold til hinanden.

Hvad Lebra beskriver her, er en grundlæggende tilgang til „det sociale“ i Japan, som tager sit udgangspunkt i det relationelle rum og i gensidig afhængighed (Rosenberger 1992; Maynard 1997). Det er mødet, der konstituerer de deltagende parter, frem for den anden vej rundt. Der forefindes utallige eksempler på dette i japanske koncepter som $b a$ (et relationelt rum for gensidig afhængighed) (Hanks et al. 2019), uchi/soto (inde/ude, den relationelle, rumlige konstituering af selv og anden) (Bachnik 1994; Quinn 1994) foruden kata og filosofien i shintospiritualitet, som jeg undersøgte ovenfor. Grunden til, at jeg har valgt at fremhæve sprogets relationelle logik her, er, at det japanske sprog rummer et struktureret mønster for samvær, som kan benyttes af både Erica og sekretærerne. Disse møder, foreslår jeg, fungerer netop, fordi de gør det muligt at fusionere kulturelt strukturerede former for samvær med algoritmiske forudsigelser af adfærd. Forholdet mellem Erica og sekretærerne bliver dermed asymmetrisk (i Lebras forstand), idet Erica og sekretærerne benytter sig af de samme udtryk for adfærd, men bruger dem forskelligt. Sekretærerne tilpasser sig Ericas kommunikationslogik, samtidig med at de benytter et kulturelt repertoire, der fremstiller Erica som en ligeværdig samtalepartner. Men Erica kan ikke tilpasse sig sekretærerne på samme måde, som de gør. For hende er kommunikationssystemet ikke et værktøj til tilpasning, men til algoritmiske forudsigelser af de potentielle variabler, som en struktureret kommunikation kan tage. Når sekretærerne tilpasser sig Erica, må de følge det foreskrevne mønster af kulturelle tegn for at imødekomme Erica på hendes niveau. Erica benytter sig af de samme kulturelt medierede tegn for at udtrykke sin menneskelighed, men måden, hun benytter sig af disse tegn på, forbliver rigid. Dette så vi blandt andet, da Erica først kunne aflæse Suzukis svar på, om hun var en indeperson, da Suzuki omformulerede svaret til en entydig bekræftelse. Når relationen gennem menneske-robot-interaktion kalibreres på denne måde, bliver det mennesket, der må tilpasse sig robotten ved at følge en standardiseret struktur for adfærd, som robotten ikke kan afvige fra. 
Relationen mellem Erica og sekretærerne bliver dermed i robotforskernes iscenesættelse til en kommunikativ udveksling, der godt nok tager udgangspunkt i menneskelig adfærd, men hvor denne adfærd er kalibreret til de tegn, som robotter og mennesker kan udveksle inden for en struktureret form. I robot-menneske-mødet opstår en form, som er både kulturelt medieret og algoritmisk kodet. Det, jeg har beskrevet i artiklen, er netop sammenfaldet mellem kulturelle forskrifter for socialt samvær og den tekniske programmering af menneskelig adfærd. Dette sammenfald er ikke givet, men kræver en aktiv kalibrering af både samvær og adfærd, for at det kan iscenesættes som en relation.

\section{Konklusion}

Jeg har igennem artiklen fokuseret på, hvordan robot-menneske-relationen iscenesættes. Min læsning af den eksisterende litteratur på området fremhævede, hvordan robotforskere i Japan trækker på kulturelle troper og traditionelle værdier, for at deres robotter kan accepteres i den bredere befolkning. Men også at det relationelle forhold mellem robotter og mennesker i Japan muligvis ikke er så afgrænset til at begynde med, og at robot-menneske-relationen derfor har et brugbart fundament at bygge på her. Efterfølgende viste jeg, hvordan kalibreringen af robot-menneske-relationen i IRL's og HIL's dynamiske interaktioner behandler både mennesker og robotter som kommunikationssystemer, der må afstemmes i forhold til en fælles kommunikativ form. Dette arbejde medfører, at robotter og mennesker bliver standardiserede efter forskernes kortlagte strukturer for menneskelig adfærd. Denne adfærd skal på en gang kunne kodes til robotters algoritmiske programmering $o g$ kunne udtrykkes i repertoirer af kulturelt medierede tegn på affinitet. Som vi så i eksemplerne med Erica, lykkes dette langtfra altid og kræver, at både mennesket og Erica kan afstemmes til det samme kommunikative mønster, om end de bruger det forskelligt. Iscenesættelsen af et sådant møde illustrerede laboratoriernes måde at definere en relation på. Relationen imellem forsker og robot skabes på sin vis af den iscenesatte form i sig selv. Relationen defineres på den ene side af det fælles kommunikative mønster, de benytter sig af (ækvivalent til den Kohnske form), og den defineres på den anden side ud fra det, som kommunikationen udtrykker i Ericas og hendes samtalepartneres sproglige og kropslige performance (ækvivalent til kata og betingelseslogikkens sproglige struktur). I IRL's og HIL's relationsskabende arbejde er det netop iscenesættelsen af relationen, der artikulerer mennesket på en bestemt måde. Dette arbejde er langtfra en neutral, teknisk praksis. Robotforskerne arbejder med standarder, som robotter og mennesker kan leve op til, men fremstiller dermed også robotter og mennesker ud fra generaliserede adfærdsmønstre, som er kulturelt betingede, men 
som fremstilles som naturlige mønstre for samvær. De kommunikationsmønstre, som professor Ishiguro forsøger at få Erica til at tage del i, hviler på kulturelle koder, der er omdannet til generelle strukturer for adfærd. Kalibreringen, som jeg har beskrevet her, kan kun fungere, når både Erica og hendes samtalepartner overholder visse kulturelle koder for adfærd og udtrykker deres rolle i overensstemmelse hermed. Hvordan man får betydning som menneske, afhænger af, hvor godt man kan udtrykke den passende rolle, som formen foreskriver. Det bliver således et spørgsmål om, hvem der kan passe ind i disse mønstre, og hvilken adfærd der bliver gjort „,naturlig“ i robotforskernes arbejde.

For en kommende diskussion af dette emne er der dermed grund til at stille spørgsmål ved de værdier, der er indarbejdet i de adfærdsmønstre, som robotforskerne arbejder med. Spørgsmålet bliver her, hvem der inkluderes eller ekskluderes i en sådan standardisering, og hvilke standarder der kommer til at tælle. Robotforskernes arbejde med at kalibrere møder mellem mennesker og robotter illustrerer, at om end det ved første øjekast er humanoide robotter, der er skabt i det menneskelige billede, er det måske i højere grad mennesket, der må standardiseres til robottens kulturelt værdiladede algoritme for at tilpasse sig deres fælles fremtid.

\section{Noter}

1. Jeg kunne her have valgt mange andre eksempler på forfattere, der behandler disse emner, da de nævnte fænomener er så velbehandlede i antropologen, at de efterhånden næsten er selvindlysende. Når disse begreber artikuleres gennem professor Ishiguro og hans robotforskeres arbejde, ophører selvfølgeligheden.

2. Om end professor Ishiguros udsagn ofte skal tages med et gran salt, er netop interaktion et grundprincip, som rent faktisk anvendes i IRL's og HIL's arbejde. Professor Ishiguro som karismatisk leder og hans måde at italesætte vigtigheden af det arbejde, de udfører, kræver en analyse i sig selv. For en diskussion af dette, se Hoeck (under udgivelse 2021).

3. Alle navne er anonymiserede på nær Hiroshi Ishiguro og Minato, som allerede har givet lov til at blive nævnt ved navn.

4. Der er en væsentlig kønsdiskussion her, som ville kræve en selvstændig artikel. For yderligere behandling af emnet, se Robertson (2007, 2018) og Hoeck (2021).

\section{Litteratur}

Bachnin, Jane M.

1994 Introduction. Uchi/Soto. Challenging our Conceptualization of Self, Social Order, and Language. In: J.M. Bachnin \& C.J. Quinn (eds): Situated Meaning. Inside and Outside in Japanese Self, Society, and Language. Pp. 3-37. New Jersey: Princeton University Press. 
Bateson, Gregory

1972 Steps to an Ecology of Mind. Essays in Anthropology, Psychiatry, Evolution and Epistemology. Northvale, NJ, \& London: Jason Aronson Inc.

Berthin, Michael

2014 Touch Future x ROBOT. Examining Production, Consumption, and Disability at a Social Robot Research Laboratory and a Centre for Independent Living in Japan. London: London School of Economics. http://etheses.1se.ac.uk/1010/1/Berthin Touch_Future_x_ROBOT.pdf.

Clammer, John

2005 The Politics of Animism. In: J. Clammer, S. Poirier \& E. Schwimmer (eds): Figured Worlds. Ontological Obstacles in Intercultural Relations. Pp. 83-109. Toronto, Buffalo, London: University of Toronto Press.

Coeckelbergh, Mark

2013 Pervasion of What? Techno-Human Ecologies and their Ubiquitous Spirits. AI \& Society 28:55-63. https://doi.org/10.1007/s00146-012-0418-y.

Cox, Rupert

2003 The Zen Arts. An Anthropological Study of the Culture of Aesthetic Form in Japan. London \& New York: Routledge.

Geraci, Robert M.

2006 Spiritual Robots. Religion and Our Scientific View of the Natural World. Theology and Science 4(3):229-46. https://doi.org/10.1080/14746700600952993.

Hanks, William F., Sachiko Ide, Yasuhiro Katagiri, Scott Saft, Yoko Fujii \& Kishiko Ueno 2019 Communicative Interaction in Terms of Ba Theory. Towards an Innovative Approach to Language Practice. Journal of Pragmatics 145:63-71. https://doi.org/ 10.1016/j.pragma.2019.03.013.

Helmreich, Stefan

2009 Alien Ocean. Anthropological Voyages in Microbial Seas. Berkeley, Los Angeles \& London: University of California Press. https://doi.org/10.1525/ 9780520942608 .

Hoeck, Kristian

2021 PhD Thesis. (Under udgivelse). Manchester: University of Manchester.

Ingold, Tim

2008 Bringing Things to Life. Creative Entanglement in a World of Materials. Aberdeen: Department of Anthropology University of Aberdeen. https://hummedi a.manchester.ac.uk/schools/soss/morgancentre/research/wps/15-2010-07-realitiesbringing-things-to-life.pdf.

Ishiguro, Hiroshi

2006 Interactive Humanoids and Androids as Ideal Interfaces for Humans. Proceedings of the $11^{\text {th }}$ international conference on Intelligent user interfaces (IUI '06). Association for Computing Machinery, New York. Pp. 2-9. https://doi.org/10.1145/ 1111449.1111451.

Ishiguro, Hiroshi, Maryam Alimardani \& Shuichi Nishio

2013 Humanlike Robot Hands Controlled by Brain Activity Arouse Illusion of Ownership in Operators. Scientific Reports 3:2396. https://doi.org/10.1038/ srep02396. 
Ishiguro, Hiroshi, denobu Sumioka, Shuichi Nishio, Takashi Minato \& Ryuji Yamazaki

2014 Minimal Human Design Approach for Sonzai-Kan Media. Investigation of a Feeling of Human Presence. Cogn Comput 6:760-74. https://doi.org/10.1007/ s12559-014-9270-3.

Jensen, Casper Bruun \& Anders Blok

2013 Techno-Animism in Japan. Shinto Cosmograms, Actor-Network Theory, and the Enabling Powers of Non-Human Agencies. Theory, Culture \& Society 30(2):84115. https://doi.org/10.1177/0263276412456564.

Kohn, Eduardo

2013 How Forests Think. Toward an Anthropology Beyond the Human. Berkeley, Los Angeles \& London: University of California Press. https://doi.org/10.14237/ ebl.7.1.2016.550.

Kubo, Akinori

2010 Technology as Mediation. On the Process of Engineering and Living with the “AIBO" Robot. Japanese Review of Cultural Anthropology 11:103-23. https: //doi.org/10.14890/jrca.11.0_103.

Lebra, Takie Sugiyama

2004 The Japanese Self in Cultural Logic. Honolulu: University of Hawai'i Press. https: //doi.org/10.1111/j.1548-1352.2010.01121.x.

Leeson, Christina

2017 Anthropomorphic Robots on the Move. A Transformative Trajectory from Japan to Danish Healthcare. Ph.d.-afhandling. Institut for Antropologi. København: Københavns Universitet.

Maynard, Senko K.

1997 Japanese Communication. Language and Thought in Context. Honolulu: University of Hawai'i Press. https://doi.org/10.1515/9780824863074.

Mori, Masahiro

1970 Bukimo no tani. [The Uncanny Valley]. Energy 7(4):33-35.

Otsuki, Grant

2015 Human and Machine in Formation. An Ethnographic Study of Communication and Humanness in a Wearable Technology Laboratory in Japan. Toronto: Department of Anthropology, University of Toronto.

Peirce, Charles Sanders

1955 Logic as Semiotic. The Theory of Signs. In: J. Buchler (ed.): Philosophial Writings of Peirce. New York: Dover Publications Inc.

Quinn, Charles J.

1994 The Terms Uchi and Soto as Windows on a World. In: J. Bachnin \& C.J. Quinn (eds): Situated Meaning. Inside and Outside in Japanese Self, Society, and Language. Princeton University Press, Pp. 38-72. https://doi.org/10.1515/ 9780691194455

Richardson, Kathleen

2016 Technological Animism. The Uncanny Personhood of Humanoid Machines. Social Analysis 60(1):110-28. https://doi.org/10.3167/sa.2016.600108.

Robertson, Jennifer

2007 Robo Sapiens Japanicus. Humanoid Robots and the Posthuman Family. Critical Asian Studies 39(3):369-98. https://doi.org/10.1080/14672710701527378. 

https://doi.org/10.1177/1357034X10364767.

2017 Robo Sapiens Japanicus. Robots, Gender, Family, and the Japanese Nation.

Berkeley: University of California Press. https://doi.org/10.1525/9780520959064.

Rosenberger, Nancy Ross

1992 Japanese Sense of Self. Cambridge: Cambridge University Press.

Šabanović, Selma

2014 Inventing Japan's “Robotics Culture”. The Repeated Assembly of Science, Technology, and Culture in Social Robotics. Social Studies of Science 44(3):34267. https://doi.org/10.1177/0306312713509704.

Schodt, Frederik L.

1988 Inside the Robot Kingdom. Japan, Mechatronics, and the Coming Robotopia. Tokyo: Kodansha International.

Strathern, Marilyn

1988 The Gender of the Gift. Berkeley, Los Angeles, London: University of California Press.

2014a Becoming Enlightened About Relations. ASA FIRTH LECTURE 2014. Anthropology and Enlightenment, ASA decennial conference in Edinburgh.

2014b Reading Relations Backwards. Journal of the Royal Anthropological Institute 20(1): 3-19. https://doi.org/10.1111/1467-9655.12076.

Suchman, Lucy

2011 Subject Objects. Feminist Theory 12(2):119-45. https://doi.org/10.1177/ 1464700111404205 .

Viveiros de Castro, Eduardo

1998 Cosmological Deixis and Amerindian Perspectivism. The Journal of the Royal Anthropological Institute 4(3):469-88. https://doi.org/10.2307/3034157.

Wagner, Cosina

2009 The Japanese Way of Robotics. Interacting "Naturally" with Robots as a National Character? RO-MAN 2009 - The 18th IEEE International Symposium on Robot and Human Interactive Communication, Toyama. Pp. 510-15. doi:10.1109/

ROMAN.2009.5326221. 